\title{
Multicomponent Approach to the Synthesis of 4-(1H-indol-3-yl)-5-(4-methoxyphenyl)furan-2(5H)-one
}

\author{
Andrey N. Komogortsev *D, Boris V. Lichitsky and Valeriya G. Melekhina \\ N.D. Zelinsky Institute of Organic Chemistry, Russian Academy of Science, Leninsky Pr., 47, \\ 119991 Moscow, Russia; blich2006@mail.ru (B.V.L.); melekhinavg@gmail.com (V.G.M.) \\ * Correspondence: dna5@mail.ru
}

check for updates

Citation: Komogortsev, A.N.; Lichitsky, B.V.; Melekhina, V.G Multicomponent Approach to the Synthesis of 4-(1H-indol-3-yl)-5-(4methoxyphenyl)furan-2(5H)-one. Molbank 2021, 2021, M1292.

https://doi.org/10.3390/M1292

Academic Editor: Raffaella Mancuso

Received: 1 October 2021

Accepted: 27 October 2021

Published: 29 October 2021

Publisher's Note: MDPI stays neutral with regard to jurisdictional claims in published maps and institutional affiliations.

Copyright: (c) 2021 by the authors. Licensee MDPI, Basel, Switzerland. This article is an open access article distributed under the terms and conditions of the Creative Commons Attribution (CC BY) license (https:// creativecommons.org/licenses/by/ $4.0 /)$.
Abstract: A simple one-pot approach was developed for the synthesis of furan-2(5H)-one derivative containing indole fragments. This method includes the telescoped multicomponent reaction of indole, 4-methoxyphenylglyoxal, and Meldrum's acid. The synthetic utility of the prepared furan2(5H)-one was demonstrated by condensation with 4-methoxybenzaldehyde. The advantages of this method include the employment of readily accessible starting materials, atom economy, process simplicity, and the easy isolation of the target products. The structure of the synthesized furanones was confirmed by ${ }^{1} \mathrm{H}$ and ${ }^{13} \mathrm{C}-\mathrm{NMR}$ spectroscopy and high-resolution mass spectrometry with electrospray ionization (ESI-HRMS).

Keywords: furan-2(5H)-one; indole; arylglyoxals; Meldrum's acid; multicomponent reaction

\section{Introduction}

Furan-2(5H)-one derivatives ( $\gamma$-butenolides) are a very important class of heterocyclic compounds thanks to their natural occurrence and noteworthy biological activities [1-3]. As an example, the cardiotonic properties of steroids containing furanone moiety (cardenolides) are well documented [4,5]. Various compounds containing the $\gamma$-butenolide core possess cytotoxic [6], antibacterial [7], and anti-inflammatory activities [8,9]. In addition, furan-2(5H)-one derivatives have been tested as peroxisome proliferator-activated receptors $(\operatorname{PPAR} \alpha)$ agonists employed in the treatment of dyslipidemia and diabetes [10].

Various methods for the synthesis of the butenolide core are described in the literature. Most often, gamma-keto acids and their derivatives are used as starting compounds [11,12], the intramolecular cyclization of which leads to furan-2-ones. Another common approach is the use of transition-metal-catalyzed coupling reactions $[13,14]$. Although many methods are known regarding the synthesis of furan-2(5H)-one moiety [15-18], some examples of multicomponent reactions (MCRs) used for the preparation of $\gamma$-butenolides are presented in the literature [19-23].

It should be noted the indole is one of the most widespread classes of heterocyclic compounds presented in the variety of natural products and synthetic biologically active substances [24-28]. In this regard, the introduction of an indole substituent into the structure of furan-2 $(5 \mathrm{H})$-one can led to the essential modification of the pharmacological properties. Thus, the elaboration of a novel multicomponent approach to the synthesis of furan-2(5H)-ones containing indole substituents is of great interest.

\section{Results and Discussion}

Herein, we disclosed a highly efficient approach to 4-(1H-indol-3-yl)-5-(4-methoxyphenyl) furan-2(5H)-one 1 on the basis of the MCR of indole 2, 4-methoxyphenylglyoxal 3, and Meldrum's acid 4 (Scheme 1). Previously, we have shown that the analogous synthesis of substituted furan-2(5H)-ones containing $4 H$-chromen-4-one fragment is a two-stage telescoped process $[26,29]$. Wherein, the starting step includes the interaction of components in acetonitrile (MeCN) to form unstable intermediates, which under the action of acidic 
reagents are transformed into the final products. In the present communication, it was demonstrated that for the synthesis of target compound $\mathbf{1}$, the optimal conditions are the reflux in $\mathrm{MeCN}$ for $1 \mathrm{~h}$ with the use of triethylamine as the basic reagent. Further reflux in acetic acid $(\mathrm{AcOH})$ for $30 \mathrm{~min}$ allows to synthesizing furanone $\mathbf{1}$ with a $74 \%$ yield.

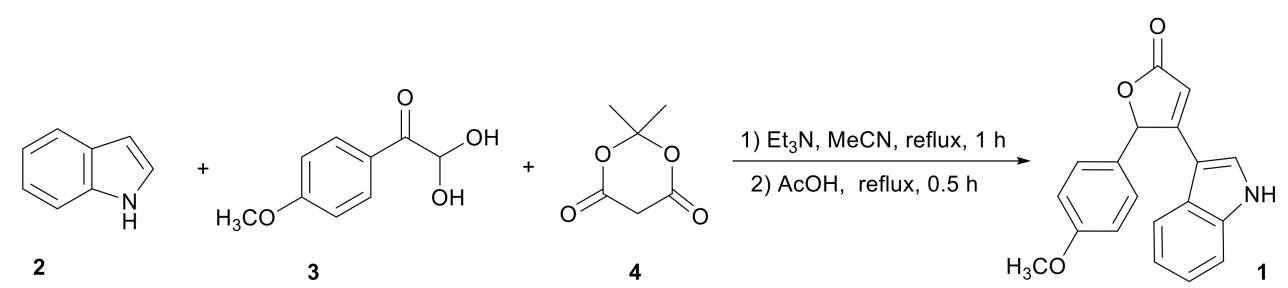

Scheme 1. Synthesis of 4-(1H-indol-3-yl)-5-(4-methoxyphenyl)furan-2(5H)-one 1.

A plausible pathway of the considered process is demonstrated in Scheme 2. At first, the condensation of Meldrum's acid 4 with arylglyoxal 3 results in the formation of a Michael acceptor $\mathbf{A}$. Then, adduct $\mathbf{B}$ is formed via the subsequent addition of indole $\mathbf{2}$ to intermediate A. Next, the acid-catalyzed intramolecular cyclization of the intermediate D includes the enolization of carbonyl moiety and the interaction of the hydroxy group with Meldrum's acid fragments. The elimination of $\mathrm{CO}_{2}$ and acetone molecules leads to furan-2(3H)-ones $\mathbf{E}$. The conclusive step of the process is the isomerization of $\mathbf{E}$ into target furan-2(5H)-one 1.

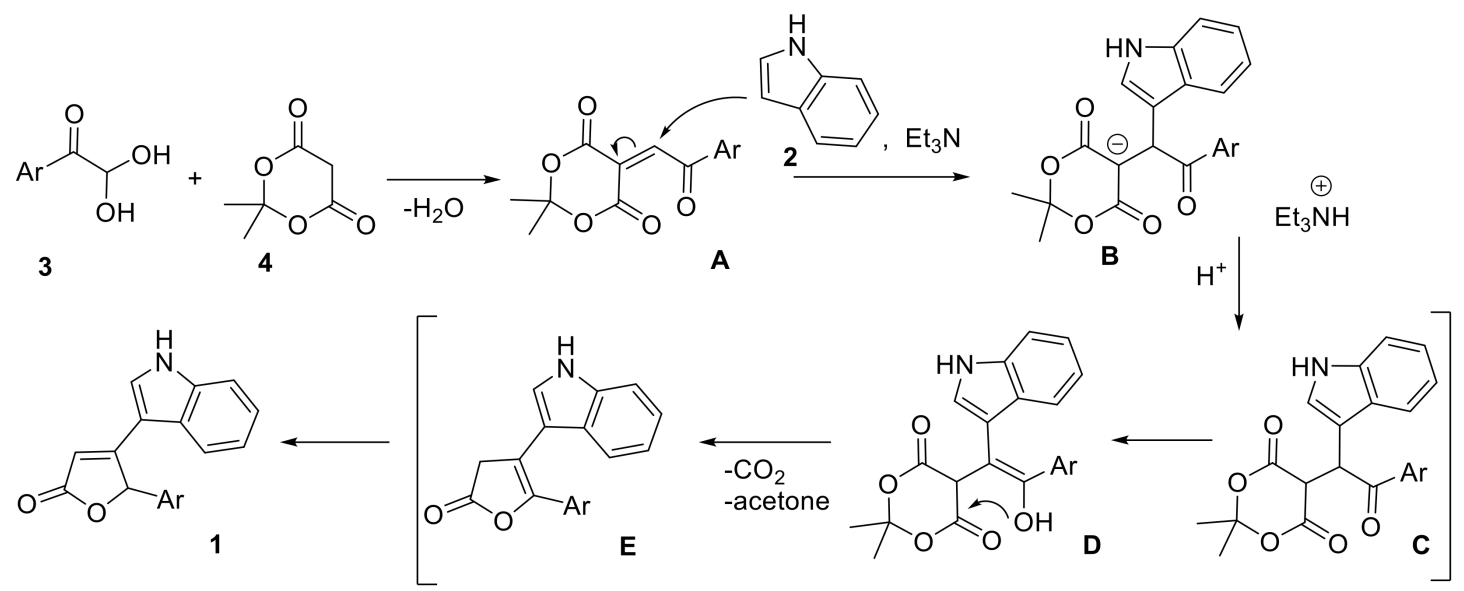

Scheme 2. Proposed reaction mechanism for the formation of furan-2(5H)-one $\mathbf{1}$.

The synthetic utility of the synthesized 4-(1H-indol-3-yl)-5-(4-methoxyphenyl)furan$2(5 \mathrm{H})$-one 1 is shown by reaction with 4-methoxybenzaldehyde 5 . As a result of the interaction, a previously unknown 4-(1H-indol-3-yl)-3-(4-methoxybenzylidene)-5-(4-methoxyphenyl) furan-2(3H)-one 6 was obtained with a $84 \%$ yield. The use of an equivalent amount of piperidine in the refluxing ethanol for 1 hour is the optimal conditions for the considered condensation (Scheme 3).

In conclusion, we elaborated a novel efficient method for the synthesis of 4-(1Hindol-3-yl)-5-(4-methoxyphenyl)furan-2(5H)-one 1. This approach based on the telescoped multicomponent condensation of indole 2, 4-methoxyphenylglyoxals 3, and Meldrum's acid 4 . The synthetic utility of the prepared furan-2(5H)-one $\mathbf{1}$ was demonstrated by reaction with 4-methoxybenzaldehyde 5 . 


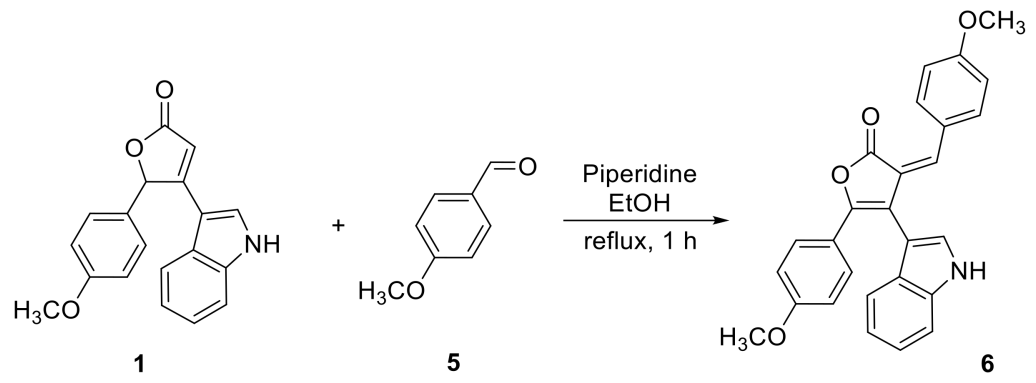

Scheme 3. Synthesis of 4-(1H-indol-3-yl)-3-(4-methoxybenzylidene)-5-(4-methoxyphenyl)furan2(3H)-one 6.

\section{Materials and Methods}

All starting chemicals and solvents were commercially available and were used as received. NMR spectra were recorded with a Bruker AM $300(300 \mathrm{MHz})$ spectrometer in DMSO- $d_{6}$. Chemical shifts (ppm) were given relative to solvent signals (DMSO- $d_{6}$ : $2.50 \mathrm{ppm}\left({ }^{1} \mathrm{H}\right.$ NMR) and $39.52 \mathrm{ppm}\left({ }^{13} \mathrm{C}\right.$ NMR)). High-resolution mass spectra (HRMS) were obtained on a Bruker micrOTOF II instrument using electrospray ionization (ESI). The melting points were determined on a Kofler hot stage.

\subsection{Synthesis of 4-(1H-Indol-3-yl)-5-(4-methoxyphenyl)furan-2(5H)-one $\mathbf{1}$}

A solution of indole $2(2 \mathrm{mmol}, 0.23 \mathrm{~g}), 4$-methoxyphenylglyoxal hydrate $3(2.2 \mathrm{mmol}$, $0.4 \mathrm{~g})$, Meldrum's acid $4(2.7 \mathrm{mmol}, 0.39 \mathrm{~g})$, and $\mathrm{Et}_{3} \mathrm{~N}(2.5 \mathrm{mmol}, 0.35 \mathrm{~mL})$ in $6 \mathrm{ml}$ of MeCN was refluxed for $1 \mathrm{~h}$. Then, the mixture was evaporated in vacuo. Six milliliters of $\mathrm{AcOH}$ were added to the residue, and the obtained solution was refluxed for $0.5 \mathrm{~h}$ and evaporated in vacuo. The residue was recrystallized from $\mathrm{EtOH}(6 \mathrm{~mL})$. The precipitate formed was collected by filtration and washed with $\mathrm{EtOH}(3 \times 5 \mathrm{~mL})$.

Brown powder; yield: $74 \%(0.45 \mathrm{~g}) ; \mathrm{mp} 197-199{ }^{\circ} \mathrm{C} .{ }^{1} \mathrm{H}$ NMR $\left(300 \mathrm{MHz}\right.$, DMSO- $\left.d_{6}\right)$ $\delta 11.78$ (br.s, 1H), 7.99-7.91 (m, 1H), 7.48-7.43 (m, 2H), $7.35(\mathrm{~d}, J=8.7 \mathrm{~Hz}, 2 \mathrm{H}), 7.26-7.15$ $(\mathrm{m}, 2 \mathrm{H}), 6.93(\mathrm{~d}, J=8.7 \mathrm{~Hz}, 2 \mathrm{H}), 6.65-6.56(\mathrm{~m}, 2 \mathrm{H})$, and $3.72(\mathrm{~s}, 3 \mathrm{H}) .{ }^{13} \mathrm{C} \mathrm{NMR}(75 \mathrm{MHz}$, DMSO- $\left.d_{6}\right) \delta 173.8,161.4,159.8,136.6,129.8,129.4,129.0,125.0,122.8,121.4,120.2,114.3$, 112.4, 107.0, 106.8, 82.9, and 55.1. HRMS (ESI-TOF) $\mathrm{m} / \mathrm{z}$ : $[\mathrm{M}+\mathrm{H}]^{+}$Calcld for $\mathrm{C}_{19} \mathrm{H}_{15} \mathrm{NO}_{3}$ 306.1125; found: 306.1131 .

\subsection{Synthesis of}

4-(1H-Indol-3-yl)-3-(4-methoxybenzylidene)-5-(4-methoxyphenyl)furan-2(3H)-one 6

The mixture of furan-2(5H)-one 1 ( $1 \mathrm{mmol}, 0.31 \mathrm{~g})$, 4-methoxyaldehyde 5 (1.2 mmol, $0.16 \mathrm{~g})$, and piperidine $(1 \mathrm{mmol}, 0.099 \mathrm{~mL})$ was refluxed for $1 \mathrm{~h}$ in $6 \mathrm{~mL}$ of EtOH. The reaction mixture was cooled, filtered off and washed with $\mathrm{EtOH}(3 \times 5 \mathrm{~mL})$.

Red powder; yield: $84 \%$ (0.36 g); mp 253-255 ${ }^{\circ} \mathrm{C} .{ }^{1} \mathrm{H}$ NMR (300 MHz, DMSO- $d_{6}$ ) $\delta 11.55$ (br.s, $1 \mathrm{H}), 8.09(\mathrm{~d}, J=9.0 \mathrm{~Hz}, 2 \mathrm{H}), 7.58-7.47(\mathrm{~m}, 2 \mathrm{H}), 7.35(\mathrm{~d}, J=9.0 \mathrm{~Hz}, 2 \mathrm{H})$, 7.20-7.12 (m, 2H), 7.01-6.90 (m, 3H), 6.86-6.77 (m, 3H), 3.80 (s, 3H), and $3.70(\mathrm{~s}, 3 \mathrm{H}) .{ }^{13} \mathrm{C}$ NMR (75 MHz, DMSO- $\left.d_{6}\right) \delta 165.9,161.3,159.8,146.8,138.9,136.5,133.8,127.6,126.7,126.0$, $125.5,121.7,121.2,119.5,119.1,114.1,114.0,112.1,111.4,111.3,103.8,55.4$, and 55.2. HRMS (ESI-TOF) $m / z$ : $[\mathrm{M}+\mathrm{H}]^{+}$Calcld for $\mathrm{C}_{27} \mathrm{H}_{21} \mathrm{NO}_{4}$ 424.1543; found: 424.1539 .

Supplementary Materials: The following are available online. Copies of ${ }^{1} \mathrm{H},{ }^{13} \mathrm{C}-\mathrm{NMR}$, and mass spectra for compound $\mathbf{1}$ and compound $\mathbf{6}$.

Author Contributions: A.N.K., conceptualization, synthesis, spectroscopic analysis, and writing of the manuscript; B.V.L., conceptualization, synthesis, spectroscopic analysis, and writing of the manuscript; V.G.M., conceptualization, synthesis, spectroscopic analysis, and writing of the manuscript. All authors have read and agreed to the published version of the manuscript.

Funding: This research received no external funding. 
Institutional Review Board Statement: Not applicable.

Informed Consent Statement: Not applicable.

Data Availability Statement: The data for the compounds presented in this study are available in the Supplementary Materials of this paper.

Conflicts of Interest: The authors declare no conflict of interest.

\section{References}

1. Avetisyan, A.A.; Dangyan, M.T. The Chemistry of $\gamma$-Butenolides. Russ. Chem. Rev. 1977, 46, 643-656. [CrossRef]

2. Mao, B.; Fañanás-Mastral, M.; Feringa, B.L. Catalytic Asymmetric Synthesis of Butenolides and Butyrolactones. Chem. Rev. 2017, 117, 10502-10566. [CrossRef] [PubMed]

3. Mandal, S.; Thirupathi, B. Strategies for the Construction of $\gamma$-Spirocyclic Butenolides in Natural Product Synthesis. Org. Biomol. Chem. 2020, 18, 5287-5314. [CrossRef] [PubMed]

4. $\quad$ El-Seedi, H.R.; Khalifa, S.A.M.; Taher, E.A.; Farag, M.A.; Saeed, A.; Gamal, M.; Hegazy, M.-E.F.; Youssef, D.; Musharraf, S.G.; Alajlani, M.M.; et al. Cardenolides: Insights from Chemical Structure and Pharmacological Utility. Pharmacol. Res. 2019, 141, 123-175. [CrossRef]

5. Michalak, M.; Michalak, K.; Wicha, J. The Synthesis of Cardenolide and Bufadienolide Aglycones, and Related Steroids Bear-ing a Heterocyclic Subunit. Nat. Prod. Rep. 2017, 34, 361-410. [CrossRef]

6. Kim, Y.; Nam, N.-H.; You, Y.-J.; Ahn, B.-Z. Synthesis and Cytotoxicity of 3,4-Diaryl-2(5H)-Furanones. Bioorg. Med. Chem. Lett. 2002, 12, 719-722. [CrossRef]

7. Husain, A.; Alam, M.M.; Shaharyar, M.; Lal, S. Antimicrobial Activities of Some Synthetic Butenolides and Their Pyrrolone Derivatives. J. Enzyme Inhib. Med. Chem. 2010, 25, 54-61. [CrossRef]

8. Ali, Y.; Alam, M.S.; Hamid, H.; Husain, A.; Shafi, S.; Dhulap, A.; Hussain, F.; Bano, S.; Kharbanda, C.; Nazreen, S.; et al. Design and Synthesis of Butenolide-Based Novel Benzyl Pyrrolones: Their TNF- $\alpha$ Based Molecular Docking with In Vivo and in Vitro. Anti-Inflammatory Activity. Chem. Biol. Drug Des. 2015, 86, 619-625. [CrossRef]

9. Yang, C.-P.; Huang, G.-J.; Huang, H.-C.; Chen, Y.-C.; Chang, C.-I.; Wang, S.-Y.; Chen, I.-S.; Tseng, Y.-H.; Chien, S.-C.; Kuo, Y.-H. A New Butanolide Compound from the Aerial Part of Lindera Akoensis with Anti-Inflammatory Activity. Molecules 2012, 17, 6585-6592. [CrossRef]

10. Igarashi, Y.; Ikeda, M.; Miyanaga, S.; Kasai, H.; Shizuri, Y.; Matsuura, N. Two Butenolides with PPAR $\alpha$ Agonistic Activity from a Marine-Derived Streptomyces. J. Antibiot. 2015, 68, 345-347. [CrossRef]

11. Liu, T.; Jia, W.; Xi, Q.; Chen, Y.; Wang, X.; Yin, D. Diversity-Oriented Synthesis of Heterocycles: Al(OTf) 3 -Promoted Cascade Cyclization and Ionic Hydrogenation. J. Org. Chem. 2018, 83, 1387-1393. [CrossRef]

12. Shimizu, K.; Kanno, S.; Kon, K. Hydrogenation of Levulinic Acid to $\gamma$-Valerolactone by Ni and MoO $\mathrm{Co}_{\mathrm{x}}$-Loaded Carbon Catalysts. Green Chem. 2014, 16, 3899-3903. [CrossRef]

13. Liu, Y.; Song, F.; Guo, S. Cleavage of a Carbon-Carbon Triple Bond via Gold-Catalyzed Cascade Cyclization/Oxidative Cleavage Reactions of (Z)-Enynols with Molecular Oxygen. J. Am. Chem. Soc. 2006, 128, 11332-11333. [CrossRef]

14. Hyde, A.M.; Buchwald, S.L. Synthesis of 5,5-Disubstituted Butenolides Based on a Pd-Catalyzed $\gamma$-Arylation Strategy. Org. Lett. 2009, 11, 2663-2666. [CrossRef]

15. Stache, E.E.; Ertel, A.B.; Rovis, T.; Doyle, A.G. Generation of Phosphoranyl Radicals via Photoredox Catalysis Enables VoltageIndependent Activation of Strong C-O Bonds. ACS Catal. 2018, 8, 11134-11139. [CrossRef]

16. Reddy, M.S.; Thirupathi, N.; Babu, M.H.; Puri, S. Synthesis of Substituted 3-Iodocoumarins and 3-Iodobutenolides via Electrophilic Iodocyclization of Ethoxyalkyne Diols. J. Org. Chem. 2013, 78, 5878-5888. [CrossRef]

17. Fu, C.; Ma, S. Efficient Preparation of 4-Iodofuran-2(5H)-Ones by Iodolactonisation of 2,3-Allenoates with I2. Eur. J. Org. Chem. 2005, 18, 3942-3945. [CrossRef]

18. Kawamata, Y.; Hashimoto, T.; Maruoka, K. A Chiral Electrophilic Selenium Catalyst for Highly Enantioselective Oxidative Cyclization. J. Am. Chem. Soc. 2016, 138, 5206-5209. [CrossRef]

19. Suero, M.G.; De la Campa, R.; Torre-Fernández, L.; García-Granda, S.; Flórez, J. Enantioselective Multicomponent Synthesis of Fused 6-5 Bicyclic 2-Butenolides by a Cascade Heterobicyclisation Process. Chem. Eur. J. 2012, 18, 7287-7295. [CrossRef]

20. Zhang, Q.; Cheng, M.; Hu, X.; Li, B.-G.; Ji, J.-X. Gold-Catalyzed Three-Component Tandem Process: An Efficient and Facile Assembly of Complex Butenolides from Alkynes, Amines, and Glyoxylic Acid. J. Am. Chem. Soc. 2010, 132, 7256-7257. [CrossRef]

21. Abbiati, G.; Rossi, E. Silver and Gold-Catalyzed Multicomponent Reactions. Beilstein J. Org. Chem. 2014, 10, 481-513. [CrossRef]

22. Nechaev, A.; Peshkov, A.; Peshkov, V.; Van der Eycken, E. The Application of Multicomponent Ugi and Passerini Reactions for the One-Pot Synthesis of Pyrrolones and Butenolides. Synthesis 2016, 48, 2280-2286. [CrossRef]

23. Beck, B.; Magnin-Lachaux, M.; Herdtweck, E.; Dömling, A. A Novel Three-Component Butenolide Synthesis. Org. Lett. 2001, 3 , 2875-2878. [CrossRef]

24. Khan, G.A.; War, J.A.; Kumar, A.; Sheikh, I.A.; Saxena, A.; Das, R. A Facile Synthesis of Novel Indole Derivatives as Poten-tial Antitubercular Agents. J. Taibah Univ. Sci. 2017, 11, 910-921. [CrossRef] 
25. Gobinath, P.; Packialakshmi, P.; Vijayakumar, K.; Abdellattif, M.H.; Shahbaaz, M.; Idhayadhulla, A.; Surendrakumar, R. Synthesis and Cytotoxic Activity of Novel Indole Derivatives and Their In Silico Screening on Spike Glycoprotein of SARS-CoV-2. Front. Mol. Biosci. 2021, 8, 255. [CrossRef]

26. Sachdeva, H.; Mathur, J.; Guleria, A. Indole Derivatives as Potential Anticancer Agents: A Review. J. Chil. Chem. Soc. 2020, 65, 4900-4907. [CrossRef]

27. Sharma, V.; Kumar, P.; Pathak, D. Biological Importance of the Indole Nucleus in Recent Years: A Comprehensive Review. J. Heterocycl. Chem. 2010, 47, 491-502. [CrossRef]

28. Kumari, A.; Singh, R.K. Medicinal Chemistry of Indole Derivatives: Current to Future Therapeutic Prospectives. Bioorg. Chem. 2019, 89, 103021. [CrossRef]

29. Lichitsky, B.V.; Melekhina, V.G.; Komogortsev, A.N.; Minyaev, M.E. A New Multicomponent Approach to the Synthesis of Substituted Furan-2(5H)-Ones Containing 4H-Chromen-4-One Fragment. Tetrahedron Lett. 2020, 61, 152602. [CrossRef] 